\title{
Benefits Management of Cloud Computing Investments
}

\author{
Richard Greenwell, Xiaodong Liu and Kevin Chalmers \\ Institute for Informatics and Digital Innovation \\ Edinburgh Napier University \\ UK
}

\begin{abstract}
This paper examines investments in cloud computing using the Benefits Management approach. The major contribution of the paper is to provide a unique insight into how organizations derive value from cloud computing investments. The motivation for writing this paper is to consider the business benefits generated from utilizing cloud computing in a range of organizations. Case studies are used to describe a number of organizations approaches to benefits exploitation using cloud computing. It was found that smaller organizations can generate rapid growth using strategies based on cloud computing. Larger organizations have used utility approaches to reduce the costs of IT infrastructure.
\end{abstract}

Keywords-Cloud Computing; Benefits Management; Information Systems Management

\section{INTRODUCTION}

Cloud computing is becoming a key component in many organizations information systems strategy. The motivation for this paper is to provide a framework for organizations to manage value from cloud investments and, to consider a Benefits Management approach towards cloud computing investments. Ward and Daniel[1] have identified high levels of dissatisfaction with the benefits derived from IT/IS projects, as shown in the table below.

TABLE I. DISSATISFACTION LEVELS WITH BENEFITS DERIVED FROM IS/IT ACTIVITIES

\begin{tabular}{|l|r|}
\hline Benefits Management activity & Level of dissatisfaction \\
\hline Identification of project costs & $43 \%$ \\
\hline Project prioritization & $59 \%$ \\
\hline Identify benefits & $68 \%$ \\
\hline Development of business cases & $69 \%$ \\
\hline Planning the delivery of benefits & $75 \%$ \\
\hline $\begin{array}{l}\text { Evaluation and review of benefits } \\
\text { realized }\end{array}$ & $81 \%$ \\
\hline
\end{tabular}

The major contribution from the paper is a unique examination of cloud computing as IS/IT investments in an analytical framework of the Benefits Management approach.

A number of case studies provide an insight into how organization of different sizes and types of use cloud computing. The investigation leads on to future work to improve the Benefits Management approach.

Cloud computing is similar to the time sharing computer services that were prevalent in IS systems in the 1960's and 1970's [2]. Grossman [3] defines cloud computing as "clouds, or clusters of distributed computers, providing on-demand resources and services over a network, usually the Internet, with the scale and reliability of a data center".

Organizations can use combinations of hardware and software as required to deliver IS/IT services with some outsourced provision if required.

A number of provision models for cloud computing exist, which are developed from the NIST standards [4]:

- Infrastructure as a Service (IaaS) - Fundamental computing resources such as hardware and software managed by another party

- Platform as a Service (PaaS) - The capability to deploy applications (created or acquired), which operate on infrastructure managed by another party

- Software as a Service (SaaS) - The ability to use applications from a number of devices managed or controlled by another party.

The models have common features such as elasticity of usage, flexibility of information storage and user self-service. The differences in the models also influence the view of cloud computing, for example IaaS and some SaaS can be seen as utilities, purchased on price PaaS and some SaaS can be used for business transformation.

A number of cloud ownership models have been observed, again defined by the NIST standards [4]:

- Public clouds are cloud infrastructure provided for open use by organization on their premises

- Private clouds are cloud infrastructure that is provisioned for exclusive use by a single organization comprising multiple consumers; that are owned, managed and operated by an organization or other parties.

- Hybrid clouds use a combination of public and private infrastructures, bound by some technology, that enables data and application portability 
Cloud computing can be linked to a number of strategic innovations, such as Big Data [5] and Data Science [6]. Low cost ubiquitous cloud computing resources can be used to process information from large datasets or databases (Big Data) and complex statistical and machine learning techniques can be applied to the data sets (Data Science).

This paper examines how a number of organizations deliver value from cloud computing investments. The methodology for the case study selection was to deliberately select organizations of different sizes and types to obtain the maximum number of IS/IT enablers and benefit types.

The paper will continue with an examination of related work on obtaining value from cloud computing Investments. A description of the Benefits Management approach pioneered by Ward and Daniel and others will follow. Four detailed case studies will then be described, followed by analysis and discussion of the case studies. Conclusions and future work complete the paper.

\section{RELATED WORK}

Ward and Daniel [1] have identified dissatisfaction with current approaches to obtaining value from IT/IS investments. The reasons they give are a focus on technology delivery and concentration on monetary measures. A number of researchers have examined value derived from cloud computing, a discussion now follows.

Moreno-Vozmediano et al. [7] focus on the technology delivery of cloud benefits. They emphasize the operational aspects of cloud management such as scalability, elasticity, security and aggregation of cloud services. Technological enablers (such as cloud investments) are not related to possible change in the business that could deliver benefits.

Low et al [8] take a multi-factor approach to cloud computing adoption and describe relative advantage, top management support, firm size and internal and external pressure as being determining factors in adoption. The paper links relative advantage in technology directly influencing cloud adoption without any connection to change or business benefits.

Misra and Mondal [9] have built a wide ranging model for cloud adoption, based on Return on Investment (ROI). The model is comprehensive and based on a number of variables such cloud resource availability, usage patterns and criticality of work the organisation carries out. This approach does not examine how benefits are delivered to businesses outside the narrow calculation of ROI. Han [10] follows in a similar vein with calculations of Total Cost of Ownership (TCO) based on fixed and variable infrastructure costs. It is important to examine costs and return on investment, as these are key factors in the adoption of cloud computing, however, stakeholders have a wider range of enablers, changes and benefits that must be examined.

Mohammed et al. [11] describe a cloud value chain reference model, based on the well-known value chain technique pioneered by Porter [12]. Monetary values are attached to cloud and business services that use the cloud services. The method concentrates solely on the monetary aspects of cloud computing adoption and fails to show linkages between technology enablers, change and benefits.

The typical examples described above concentrate on technology delivery or monetary measures of value from cloud computing investments. There is little linkage between technology enablers, change and benefits. A discussion the Benefits Management approach pioneered by researchers such as Ward and Daniel [1] now follows.

\section{The Benefits MANAGEMENT APPROACH}

Cloud computing can be viewed as an enabling IS/IT innovation and, cannot be seen as creating value or benefit in isolation. Organizations must derive benefit from the innovation and employ a mechanism to create change and business benefit within the organization. This creates a portfolio of investments within the organization that generate competencies and long term competitive advantage. The research question proposed in this paper centers around deriving benefits from technology enablers. An effective Benefits Management system must be in place to generate these benefits.

The Benefits Management approach was developed by Peppard, Daniel, Ward and Rylander [13]; Peppard and Rylander [14]; the researchers developed the approach from empirical studies of IT projects. They found that IT investments failed to deliver benefits to organizations and they aimed to address this shortfall by concentrating on maximising benefits from IT investments. The researchers argue that traditional project and investment approaches force IS project managers to overstate benefits to allow investment to take place [15]. Real benefits are ill-defined or overstated.

To overcome the issues with traditional approaches, benefits must be accurately identified and a plan must be in place to realise the benefits. Ward and Daniel [15] define the Benefits Management approach as "The process of organising and managing so that the potential benefits from IT are actually realised". Benefits Management brings together a number of techniques such as benefits realisation and change management. Peppard et al. [13] describe the benefits realisation approach as viewing IT as providing no inherent value and, with benefits only arising "When IT enabales people do things differently". Stakeholders such as business managers and users can realise business benefits which must be activily managed.

Technological enablers drive the benefits process, however, they are converted into benefits by a number of individuals, groups, processes and techniques that trigger change.

Stakeholders (users and business managers) are key to benefits realization. [13]. A critism of this view is that it ignores large groups of stakeholders within organizations [16]. Start-up companies can be technology led and, ignoring technology stakeholders could lead to potential benefits being lost. The agile approach to software development is carried out by mult-displinary teams, many of whom are technologists [17]. The Benefits Management process must capture all benefits and exploit them to be successful. The core tool for 
Benefits Management is the Benefits Depednency Network (BDN) [18] which is shown below.

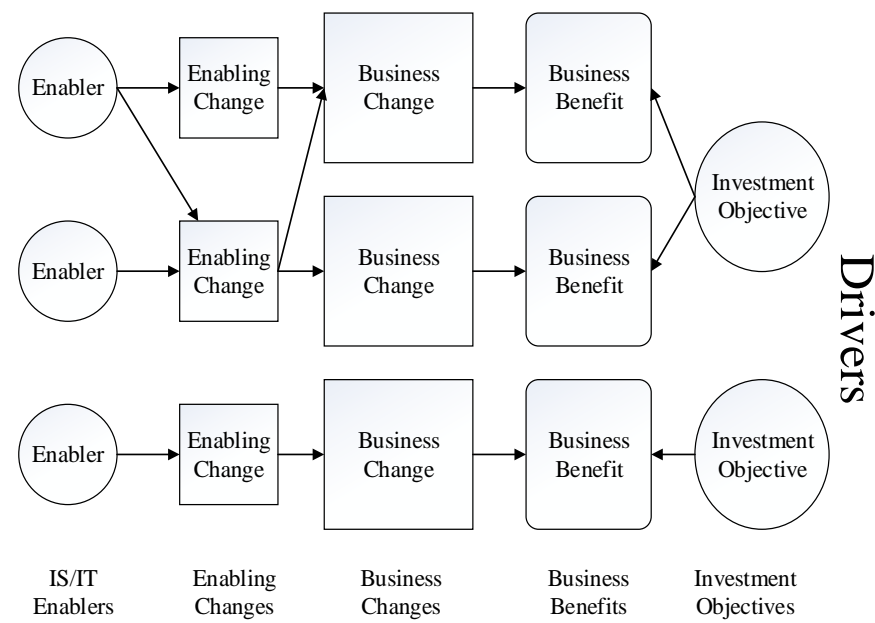

Fig. 1. Benefits Dependency Network

The BDN allows investment objectives and linked benefits to be structured, so that benefits can be realized. The BDN sees enablers generating enabling change that in turn dives business change which creates business benefits. Business benefits are linked to investment objectives in the organization. Enablers are IS/IT technology that cannot create change in isolation. Enabling changes are created through activities such as training or education which trigger business changes that generate benefits that meet investment objectives.

The table below shows the classification of benefits from the BDN. The benefits are described in terms of their degree of explicitness with financial being the most explicit, followed by quantifiable, measurable and observable benefits. An action describes future conduct for the benefit. Doing new things or doing things better with benefits and stop doing things for dis-benefits. The structuring of benefits builds on earlier work on situational analysis, for example SWOT and TOWS [19] and five forces analysis [12].

TABLE II. CLASSIFICATION OF BENEFITS MATRIX

\begin{tabular}{|l|l|c|c|}
\hline $\begin{array}{l}\text { Degree of } \\
\text { Explicitness/Action }\end{array}$ & $\begin{array}{l}\text { Do New } \\
\text { Things }\end{array}$ & $\begin{array}{c}\text { Do } \\
\text { Things } \\
\text { Better }\end{array}$ & $\begin{array}{c}\text { Stop Doing } \\
\text { Things }\end{array}$ \\
\hline Financial & & & \\
\hline Quantifiable & & & \\
\hline Measurable & & & \\
\hline Observable & & & \\
\hline
\end{tabular}

Developing a portfolio of investments allows benefits and risks to be balanced and managed effectively. An example of some aspects of cloud computing previously identified are shown in the table below. The headings of the table show groupings of high potential, strategic, key operational investments and support investments, which will now be described.
TABLE III. PORTFOLIO OF INVESTMENTS FOR CLOUD COMPUTING

\begin{tabular}{|c|c|}
\hline Strategic Investments & $\begin{array}{c}\text { High Potential } \\
\text { Investments }\end{array}$ \\
\hline SaaS & PaaS \\
Hybrid Cloud & $\begin{array}{c}\text { Private Cloud } \\
\text { Data Science } \\
\text { Big Data }\end{array}$ \\
\hline Public Cloud & IaaS \\
\hline Key Operation & Support Investments \\
Investments & \\
\hline
\end{tabular}

High potential investments provide high levels of benefits but also have high risks, and thus must be controlled carefully, except in small start-up organizations that are based around such investments. Organizations can develop new products on cloud based PaaS. There is a development risk as new software has to be created and a large financial commitment in staff and capability development is required.

Private clouds can provide a unique competency for the organization. Google and Amazon [20] have developed their own private clouds to drive their businesses. Data Science is an emerging technology that can provide significant competitive advantage, which can use cloud computing.

Strategic investments are those which require significant change over a medium to long term. Public authorities are considering SaaS solutions to reduce the cost of ownership and to outsource non-key competencies under schemes such as G-Cloud [21]. Hybrid cloud solutions which combine both public and private clouds are key strategic investments. Big Data using cloud based technology is seen as more established and pervasive than technologies such as Data Science [22].

Key operational investments improve systems and services that are critical to the organization. These investments must be tightly controlled and be low risk. Public clouds provide off the shelf computing resources that have been tested by providers. A high degree of redundancy and availability are built into public cloud offerings. Many large organizations are moving key operational systems [23] to public clouds, to provide costs savings and improve availability and reliability of systems. There are risks in loss of control and the security of intellectual property.

Support investments are low risk investments in essential systems. These investments concentrate on efficiencies and cost reduction, and are driven by standardization and waste elimination. Support investments will not generate long term competitive advantage as competitors can easily replicate standardized investments. In cloud computing IaaS provides a low cost replacement infrastructure for the organization's infrastructure.

\section{CASE STUdies}

A number of case studies were developed to examine the Benefits Management approach. The case studies concentrate on how organizations utilize cloud computing, Semistructured interviews were used to gather information. 


\section{A. Organization A - Micro Start-up Company}

Organization A was a small start-up organization with less than five employees. It used cloud technology based on PaaS and public cloud technology. The organization provides solutions to the music promotion industry. New artists create music demonstrations that are distributed to Disc Jockeys (DJs), radio stations and music venues. The company has a surprisingly large customer base, with over 2,000 customers and receives several hundred demonstration music tracks each week. A sophisticated feedback and metric system for those listening to demonstration recordings is maintained.

A major operational benefit from using cloud computing is the ability to quickly create new environments for development and live systems that can be easily moved in the cloud.

Music tracks are held in cloud storage, rather than being sent as attachments in e-mails. This gives a number of benefits. There is a single place for the storage of tracks, which has a triple backup. Tracks are downloaded on demand, thus less communications bandwidth is used.

The public cloud can be shared by Organization A and customers. This gives benefits in terms of customer intimacy. Customers can suggest changes to software that can be quickly prototyped and moved rapidly to live systems.

PaaS allows smaller innovative organizations to use the performance enhancements and the unique functionality of cloud computing. The figure below shows the benefits dependency network for Organization A, which shows the enablers, changes and benefits described.

Significant savings have been made by using cloud infrastructure of around $£ 2,400$ (UK pounds) per year. The organization has become more agile and can turn around bug fixes and deploy new functionality more quickly.

Quality of service to those receiving music tracks has been improved, as fewer e-mails are rejected due to attachment size. E-mail preparation and delivery was streamlined by using cloud storage. Delivery times were quicker by using high levels of cloud resources for the production of e-mails in short bursts.

Organization A and customers can work together on a shared development platform. This improved communication and reduced configuration problems. The benefits from the benefits dependency network were structured as shown in the table IV.

The structured benefits were used to generate an investment portfolio which is shown in table $\mathrm{V}$.

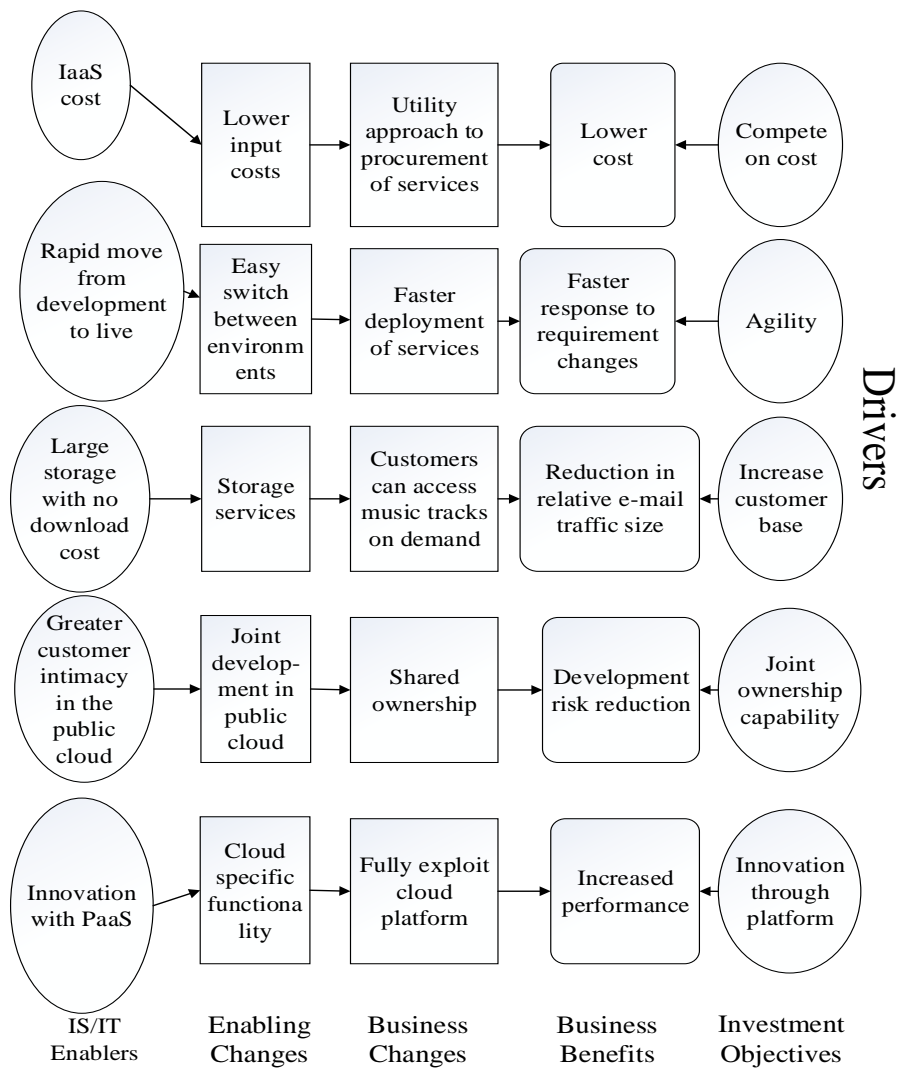

Fig. 2. Benefits Dependency Network for Organization A

TABLE IV. ClasSIFICATION OF BENEFITS FOR ORGANIZATION A

\begin{tabular}{|c|c|c|c|}
\hline $\begin{array}{c}\text { Degree of } \\
\text { Explicitness }\end{array}$ & $\begin{array}{c}\text { Do New } \\
\text { Things }\end{array}$ & $\begin{array}{l}\text { Do Things } \\
\text { Better }\end{array}$ & $\begin{array}{c}\text { Stop Doing } \\
\text { Things }\end{array}$ \\
\hline Financial & $\begin{array}{l}\text { Lower cost of } \\
\text { ownership } \\
\text { Around } £ 200 \\
\text { per month }\end{array}$ & $\begin{array}{l}\text { Develop on the } \\
\text { cloud, reduces } \\
\text { time creating } \\
\text { environments } \\
\text { and saves } \\
\text { around } £ 100 \text { per } \\
\text { month }\end{array}$ & $\begin{array}{l}\text { Managing own } \\
\text { infrastructure } \\
\text { used to cost } \\
\text { around } £ 100 \text { per } \\
\text { month }\end{array}$ \\
\hline Quantifiable & $\begin{array}{l}\text { Improved } \\
\text { quality of } \\
\text { service. } \\
\text { Problem report } \\
\text { to deployment } \\
\text { reduced by } 2 \\
\text { days }\end{array}$ & $\begin{array}{l}\text { Faster } \\
\text { turnaround of } \\
\text { new } \\
\text { functionality } \\
\text { Release cycle } \\
\text { cut by } 10 \\
\text { person days } \\
\end{array}$ & \\
\hline Measureable & $\begin{array}{l}\text { Less e-mails } \\
\text { rejected by } \\
\text { music } \\
\text { reviewers } \\
13 \% \\
\text { improvement }\end{array}$ & $\begin{array}{l}\text { Increased } \\
\text { performance } \\
\text { through PaaS } \\
\text { innovations }\end{array}$ & $\begin{array}{l}\text { Sending } \\
\text { attachments in } \\
\text { e-mails. E-mail } \\
\text { send time } \\
\text { improved by } 19 \\
\text { minutes }\end{array}$ \\
\hline Observable & $\begin{array}{l}\text { Better intimacy } \\
\text { with customer }\end{array}$ & & \\
\hline
\end{tabular}


TABLE V. INVESTMENT PORTFOLIO FOR ORGANIZATION A

\begin{tabular}{|c|c|}
\hline Strategic Investments & $\begin{array}{c}\text { High Potential } \\
\text { Investments }\end{array}$ \\
\hline $\begin{array}{c}\text { IaaS } \\
\text { Cloud storage }\end{array}$ & PaaS \\
hardware & Non-cloud based software \\
\hline $\begin{array}{c}\text { Existing customers with their own } \\
\text { Key Operation Investments }\end{array}$ & Support Investments \\
\hline
\end{tabular}

Cloud storage offers a good solution for storing large numbers of high quality music tracks. PaaS offers a mechanism for Organization A to gain competitive advantage over other organizations by using features that are unique to cloud computing, such as the ability to use a large number of virtual processing resources on demand and specialist storage systems.

\section{B. Organization B-Actuarial Services Consultancy}

Organization B is an actuarial science consultancy of around 200 employees. The organization has been taken over by a larger organization. Although the organization is now part of a larger organization, they have maintained their independence and adopt an agile management style.

The organizations product is based on building complex economic models, which are used to supply research reports to customers, such as investment banks. Previously, the models were generated on off-the-shelf high-end personal computers or expensive grid-computers. The organization utilized public cloud computing solutions based on IaaS/PaaS platforms. This has allowed economic models to be built more quickly and, at a lower cost than using in-house hardware. The total cost of ownership of infrastructure has also been reduced, as only the resources that are used are paid for and there is no administration or depreciation of IT infrastructure. The figure below shows the BDN for the Organization.

Cost is an enabler for the organization. Prior to cloud resources being available specialist high end personal computers or grid computers were required to run economic scenarios in an acceptable timeframe. The storage of each economic scenario also required several gigabytes of information, with added backup and storage infrastructure costs.

The on-demand resources provided by cloud computing allowed the elimination of waste from the organization. The expensive IT infrastructure previously described wouldn't be renewed when it came to the end of its life, as it was only used $10-20 \%$ of the time.

The ability to use potentially unlimited resources on demand was an enabling technology. Economic model scenarios were being run on a quarterly basis for most customers. Larger customers would run scenarios more frequently. The marketing aspects of cloud computing were key enablers in the adoption of cloud computing. Organization B provided a customer solution that was ahead of their competitors, by slightly reworking their well-designed software to function on a PaaS platform.
FiguRE 1 - BENEFITS DEPENDENCY NETWORK FOR ORGANIZATION B
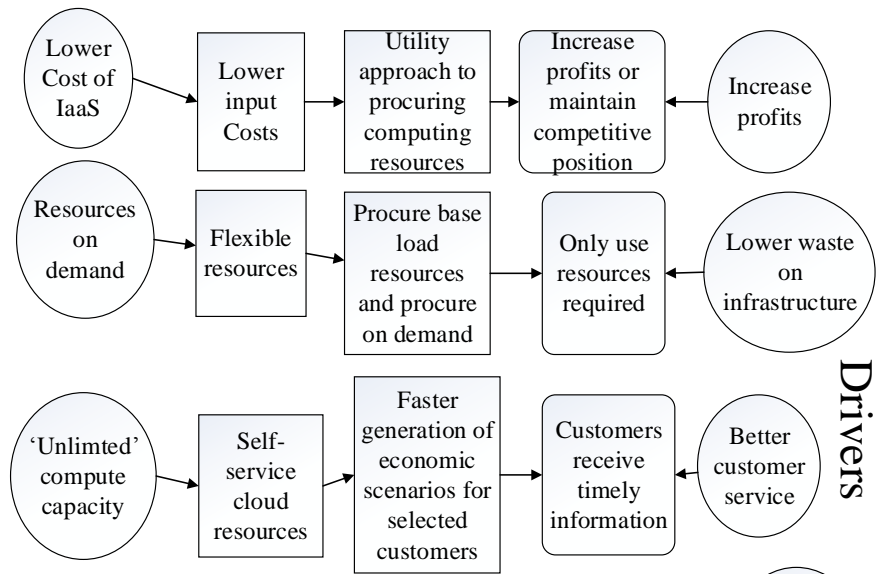

Procure base

resources
and procure

on demand
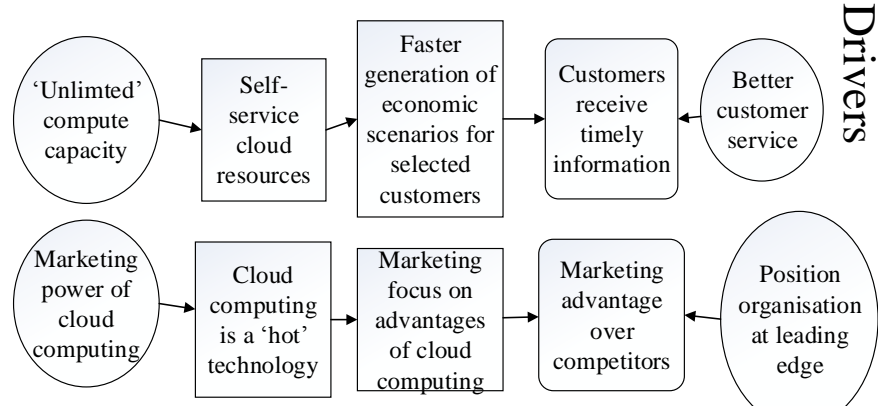

customers
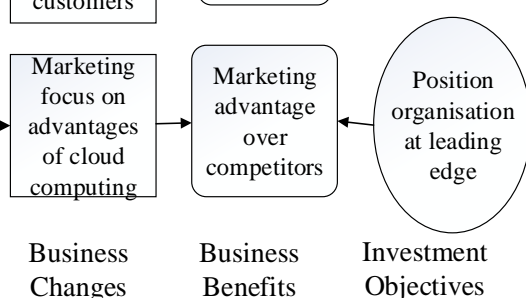

$\begin{array}{ccccc}\text { IS/IT } & \text { Enabling } & \text { Business } & \text { Business } & \text { Investment } \\ \text { Enablers } & \text { Changes } & \text { Changes } & \text { Benefits } & \text { Objectives }\end{array}$

Fig. 3. Benefits Dependency Network for Organization B

The benefits in the BDN were structured, as shown in the table below:

TABLE VI. CLASSIFICATION OF BENEFITS FOR ORGANIZATION B

\begin{tabular}{|c|c|c|c|}
\hline $\begin{array}{c}\text { Degree of } \\
\text { Explicitness }\end{array}$ & $\begin{array}{l}\text { Do New } \\
\text { Things }\end{array}$ & $\begin{array}{l}\text { Do Things } \\
\text { Better }\end{array}$ & $\begin{array}{c}\text { Stop } \\
\text { Doing } \\
\text { Things }\end{array}$ \\
\hline Financial & $\begin{array}{l}\text { Total cost of } \\
\text { scenario } \\
\text { generation } \\
\$ 12.15 \text { ( USD) } \\
\text { per scenario }\end{array}$ & & $\begin{array}{l}\text { Grid } \\
\text { Computing in } \\
\text { the long term. } \\
\text { Even grid } \\
\text { computers } \\
\text { servers cost } \\
\$ 24,900 \text { to } \\
\$ 39,900 \\
\text { (USD) }\end{array}$ \\
\hline Quantifiable & & $\begin{array}{l}\text { Speed up } \\
\text { scenario } \\
\text { generation by } \\
\text { using on- } \\
\text { demand } \\
\text { processing }\end{array}$ & \\
\hline Measureable & $\begin{array}{l}\text { Reduced } \\
\text { additional } \\
\text { costs through } \\
\text { usage of cloud } \\
\text { computing }\end{array}$ & $\begin{array}{l}\text { Saving } \\
\text { information in } \\
\text { the cloud } \\
\text { improves data } \\
\text { security and aids } \\
\text { customer } \\
\text { support }\end{array}$ & $\begin{array}{l}\text { Saving data } \\
\text { files and } \\
\text { scenarios on } \\
\text { customers } \\
\text { machines }\end{array}$ \\
\hline Observable & $\begin{array}{l}\text { Improved } \\
\text { marketing } \\
\text { image }\end{array}$ & & \\
\hline
\end{tabular}


The structured benefits from the investment portfolio are shown below.

TABLE VII. INVESTMENT PORTFOLIO FOR ORGANIZATION B

\begin{tabular}{|c|c|}
\hline Strategic Investments & $\begin{array}{c}\text { High Potential } \\
\text { Investments }\end{array}$ \\
\hline $\begin{array}{c}\text { IaaS } \\
\text { Cloud storage } \\
\text { Marketing of Cloud } \\
\text { Computing }\end{array}$ \\
\hline $\begin{array}{c}\text { Clustered Computer Servers with } \\
\text { cloud extensions }\end{array}$ & Grid Computing \\
\hline $\begin{array}{c}\text { Key Operation } \\
\text { Investments }\end{array}$ & Support Investments \\
\hline
\end{tabular}

The investment portfolio sees the usage of existing servers being clustered to provide the required processing power to generate economic scenarios. The clusters have been extended to include cloud based processing.

The long term strategy will see a move to cloud based PaaS as in-house servers and grid computers become outdated. Cloud storage was used to store scenario input data and results.

PaaS allows new computer software to be created that generates competitive advantage by using cloud features, rather than running existing software that runs on IaaS. The marketing of software that was capable of running on the cloud generates competitive advantage by being the first or an early adopter in the market.

\section{Organization C - Public Sector Division of Large Software Company}

Organization $\mathrm{C}$ was a large software development organization with 546 staff and $£ 57.2 \mathrm{M}$ (UK pounds) in revenues. The organization specialized in a number of markets, such as transport and public sector administration.

The public sector division has been heavily involved in the UK government G-Cloud project. G-Cloud aims to provide a framework for the government provision of cloud computing by companies across IaaS, PaaS and SaaS [23]. Organization $\mathrm{C}$ also supplies specialist cloud services to individual customers outside the G-Cloud program.

The benefits dependency network shown above sees the GCloud processes and platforms being pivotal to the future of Organization C's public sector division. The core cloud models used are IaaS and SaaS.

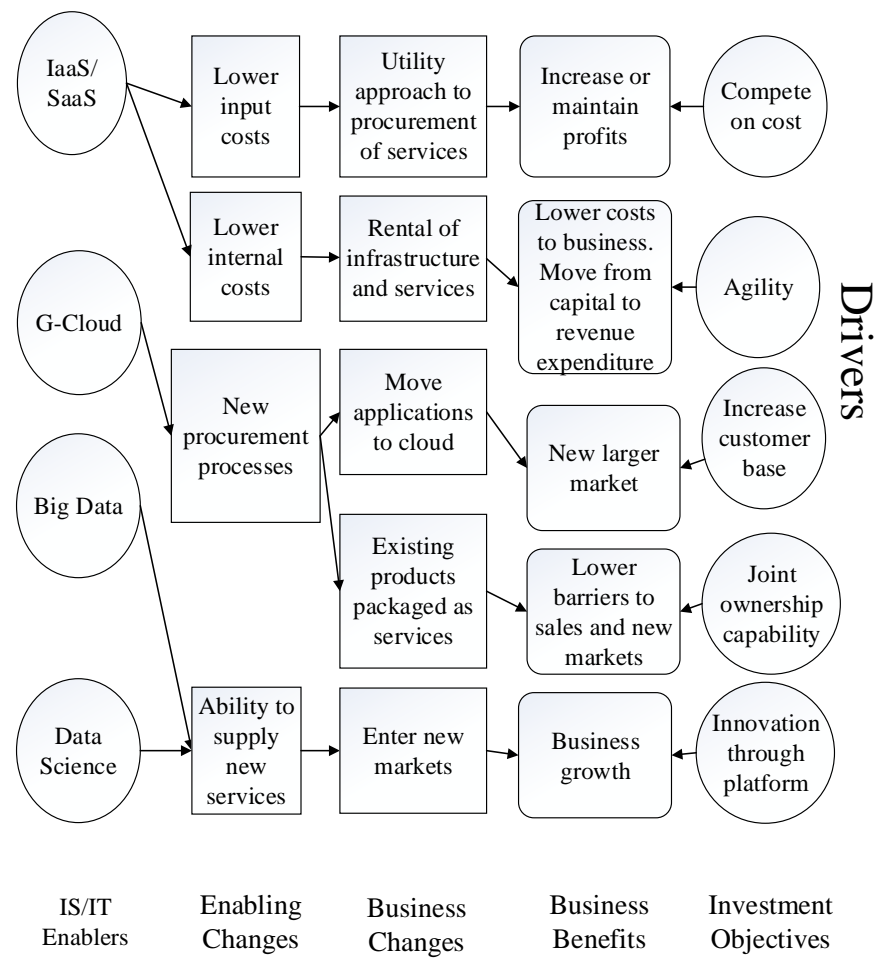

Fig. 4. Benefits Dependency Network for Organization C

New high value and growth sectors are Big Data and Data Science applications built on cloud platforms.

Organization C only uses IaaS and SaaS models and, sees the two services as utilities that can be purchased from a number of suppliers. Cloud computing replaces their current infrastructure, delivery mechanisms to customers of in-house hardware and hosted services. Organization C's internal infrastructure is being replaced by cloud infrastructure to lower costs.

The G-Cloud program and platforms provide access to new markets and change the way software is delivered. New markets have been opened up, allowing greater access to UK government markets and new overseas markets. The cost of entry into markets has been lowered. The organization must be proactive in finding customers.

Emerging Big Data and Data Science enablers has allowed new services to be developed, for example economic analytics, which can be sold to government departments. Benefits are structured in the table below 
TABLE VIII. CLASSIFICATION OF BENEFITS FOR ORGANIZATION C

\begin{tabular}{|c|c|c|c|}
\hline $\begin{array}{c}\text { Degree of } \\
\text { Explicitness }\end{array}$ & $\begin{array}{c}\text { Do New } \\
\text { Things }\end{array}$ & $\begin{array}{c}\text { Do Things } \\
\text { Better }\end{array}$ & $\begin{array}{c}\text { Stop Doing } \\
\text { Things }\end{array}$ \\
\hline Financial & $\begin{array}{c}\text { G-Cloud } \\
\text { market } \\
\text { potentially } \\
\text { worth } £ 11-16 \\
\text { billion. }\end{array}$ & & \\
\hline Quantifiable & $\begin{array}{l}\text { Attack market } \\
\text { - } 520 \text { times } \\
\text { increase in G- } \\
\text { cloud market } \\
\text { in } 2012-2013\end{array}$ & $\begin{array}{c}90 \% \text { cost } \\
\text { saving using } \\
\text { SaaS and IaaS } \\
\text { for internal } \\
\text { infrastructure }\end{array}$ & $\begin{array}{c}\text { Maintaining } \\
\text { internal } \\
\text { infrastructure to } \\
\text { save money }\end{array}$ \\
\hline Measureable & $\begin{array}{l}\text { New Markets } \\
\text { for Big Data } \\
\text { and Data } \\
\text { Science }\end{array}$ & & \\
\hline Observable & $\begin{array}{l}\text { Move from } \\
\text { project based } \\
\text { solutions to } \\
\text { product based } \\
\text { solutions, to } \\
\text { create utility } \\
\text { products }\end{array}$ & $\begin{array}{l}\text { Actively market } \\
\text { to customers }\end{array}$ & $\begin{array}{l}\text { Waiting for } \\
\text { customers to } \\
\text { come to } \\
\text { Organization } \\
\text { As prime public } \\
\text { sector provider }\end{array}$ \\
\hline
\end{tabular}

The table below shows Organization C's investment portfolio. The enablers from the benefits dependency network create strategic and high potential investments. The main investments are in the G-Cloud program. Existing investments in private and public clouds are supported or are key operational investments in the portfolio.

TABLE IX. INVESTMENT PORTFOLIO FOR ORGANIZATION C

\begin{tabular}{|c|c|}
\hline Strategic Investments & $\begin{array}{c}\text { High Potential } \\
\text { Investments }\end{array}$ \\
\hline SaaS (utility) & G-Cloud \\
Big Data \\
IaaS (utility)
\end{tabular}

\section{Organization D - Public Sector Managed Services}

Organization D was an innovative shared service information technology operation between two local government authorities and an IaaS/SaaS provider. Organization D has used cloud computing to provide a school academy finance management system that uses SaaS.

The advantage of this approach was seen as outsourcing some hardware (IaaS) and software (SaaS) ownership to an outside organization. This allowed the expertise of the provider to be used and, therefore reduced risk and the cost of ownership of infrastructure. The disadvantages were a loss of control in the development of the service, control of costs and loss of knowledge within the local authority.

All public sector organizations in the UK operate under the Value for Money (VFM) framework, this forces organizations to consider cost savings which are driving the rapid uptake of cloud computing. Flexibility is a second enabler for the organization's adoption of cloud computing. The organization can use their existing hardware for a "base load" and additional resources can be provided by public clouds.

The shared ownership model introduced into the organization with cloud computing allows the organization to share risk with commercial partners and gain commercial income. The organization can also acquire new skills.

Improved service delivery is the final enabler. There was greater availability of infrastructure. Users can use self-service systems to request new software services. New licenses for software are automatically billed back to managers, who could view bills via management information dashboards. The BDN for Organization D is shown in the figure below.

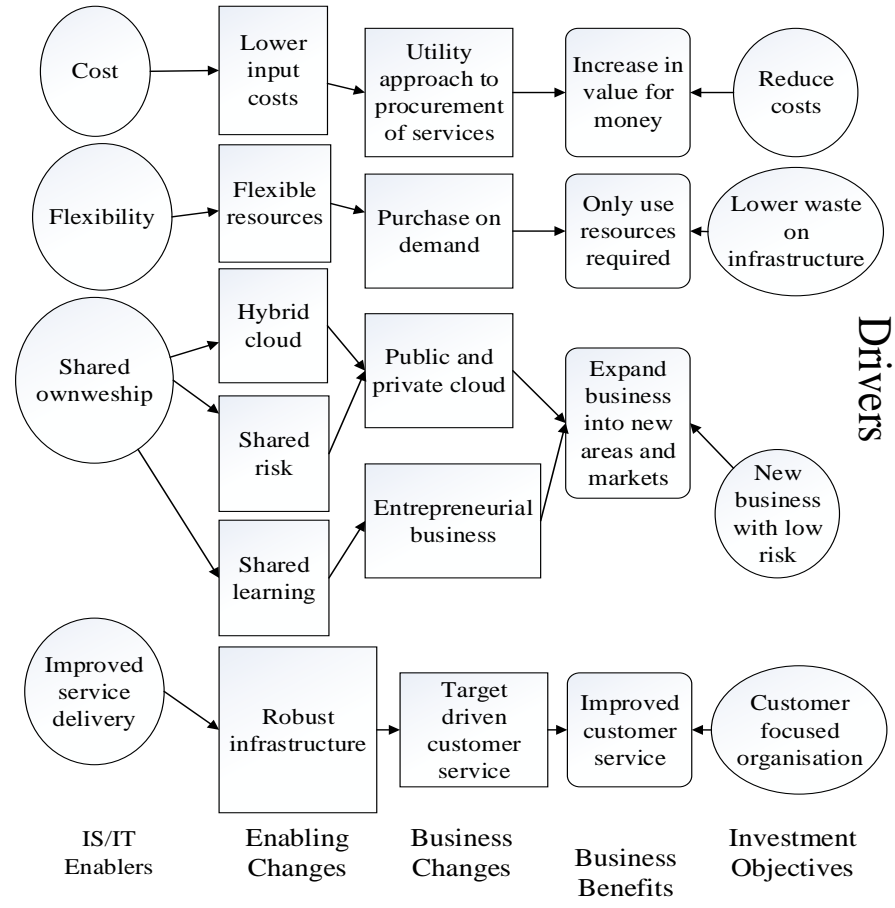

Fig. 5. Benefits Dependency Network for Organization D

The benefits from the BDN are structured in the table below. Major costs savings have been made on infrastructure. The self-service aspects of the cloud infrastructure have reduced the number of service calls. The availability of infrastructure and applications is now approaching $100 \%$. Customer satisfaction has increased from 3.9/5.0 to 4.1/5.0. The local authority has managed to attract two new external customers.

Organization D's investment portfolio is shown below. The main investments are in IaaS and SaaS. Cloud infrastructure has replaced existing in-house and hosted hardware and software. The organization can bid for new business outside the public authority. 
TABLE X. CLASSIFICATION OF BENEFITS FOR ORGANIZATION D

\begin{tabular}{|c|c|c|c|}
\hline $\begin{array}{c}\text { Degree of } \\
\text { Explicitness }\end{array}$ & $\begin{array}{l}\text { Do New } \\
\text { Things }\end{array}$ & $\begin{array}{l}\text { Do Things } \\
\text { Better }\end{array}$ & $\begin{array}{l}\text { Stop Doing } \\
\text { Things }\end{array}$ \\
\hline Financial & $\begin{array}{l}£ 9.2 \mathrm{M} \text { in } \\
\text { savings over } 5 \\
\text { years }\end{array}$ & $\begin{array}{l}\text { Year on year } \\
\text { savings of } £ 1.1\end{array}$ & \\
\hline Quantifiable & $\begin{array}{l}30 \% \text { reduction } \\
\text { in service calls } \\
\text { using self } \\
\text { service }\end{array}$ & $\begin{array}{l}\text { Availability of } \\
\text { ICT systems } \\
99.21 \% \\
\text { Availability of } \\
\text { ICT } \\
\text { Infrastructure } \\
99.94 \%\end{array}$ & $\begin{array}{l}\text { Reduction of } \\
10 \text { staff } \\
\text { servicing } \\
\text { desktop } \\
\text { computers }\end{array}$ \\
\hline Measureable & & $\begin{array}{l}\text { Customer } \\
\text { satisfaction } \\
4.01 / 5\end{array}$ & \\
\hline Observable & $\begin{array}{l}2 \text { new } \\
\text { customers } \\
\text { outside } \\
\text { councils }\end{array}$ & & \\
\hline
\end{tabular}

TABLE XI. INVESTMENT PORTFOLIO FOR ORGANIZATION D

\begin{tabular}{|l|l|}
\hline Strategic Investments & High Potential Investments \\
\hline $\begin{array}{l}\text { SaaS (utility) } \\
\text { IaaS (utility) }\end{array}$ & $\begin{array}{l}\text { Shared services } \\
\text { Grow new business outside councils }\end{array}$ \\
\hline Private Cloud & Public Cloud \\
\hline \multicolumn{1}{|c|}{$\begin{array}{c}\text { Key Operation } \\
\text { Investments }\end{array}$} & Support Investments \\
\hline
\end{tabular}

\section{RESUlTS AND ANALYSIS OF CASE STUDIES}

The cloud models are important to how organizations used cloud enablers. This is shown in the table below.

TABLE XII. PROVISION MODELS USED By ORGANIZATIONS

\begin{tabular}{|l|l|l|}
\hline Models & \multicolumn{1}{|c|}{ Description } & \multicolumn{1}{c|}{ Case Study } \\
\hline IaaS & Utility based, driven by cost & $\begin{array}{l}\text { Organization D } \\
\text { Some Organization C } \\
\text { Some Organization B } \\
\text { Some Organization A }\end{array}$ \\
\hline SaaS & $\begin{array}{l}\text { Can be utility based or used to } \\
\text { generate new products }\end{array}$ & $\begin{array}{l}\text { Some Organization D } \\
\text { Some Organization C }\end{array}$ \\
\hline PaaS & $\begin{array}{l}\text { Used to generate new } \\
\text { concepts and products and } \\
\text { greater intimacy with } \\
\text { customer }\end{array}$ & $\begin{array}{l}\text { Some Organization B } \\
\text { Mostly Organization A }\end{array}$ \\
\hline
\end{tabular}

All of the organizations in the case studies use IaaS directly or as a layer below PaaS/SaaS. IaaS lowers direct costs and reduces management overheads. IaaS is becoming a utility, and is reducing in price that can be purchased by any organization (especially in the public cloud).

The table above shows that Organization A has been able to use PaaS to develop unique products that give it a competitive advantage in the market it operates in. Organization D is relying on IaaS the most, to reduce costs.

SaaS has a dual aspect, as many SaaS offerings are redevelopments of existing CRM and ERP software packages with innovations in pricing and ownership. New innovative SaaS products are also being developed, such as cloud storage, which is a disruptive technology in the disaster recovery and archival market.

The second dimension of cloud computing is the ownership model, which is shown in the table below.

TABLE XIII. Cloud Ownership MOdels OF ORganizations

\begin{tabular}{|c|c|c|}
\hline Ownership & Description & Case Study \\
\hline Public Clouds & Utility based & $\begin{array}{c}\text { Organization A, } \\
\text { Organization B }\end{array}$ \\
\hline Hybrid Clouds & Some utility aspects & $\begin{array}{l}\text { Organization D, } \\
\text { Organization C }\end{array}$ \\
\hline
\end{tabular}

Public clouds are a utility that will not deliver long term competitive advantage. Organization A has used public clouds as a low cost way to enter new markets and has relied on PaaS to innovate. Organization B is not concerned with developing competitive advantage through ownership models, as it relies on PaaS in the medium to long term. In the short term all organizations will use lower costs and marketing to generate competitive advantage.

Organization $\mathrm{C}$ and Organization $\mathrm{D}$ can use their size to purchase cloud resources at low cost. Both organizations can also invest in private clouds to develop a unique capability for processing Big Data and Data Science tasks.

Organization D used hybrid cloud technology as a strategic enabler. It combined private cloud infrastructure with low cost public cloud provision. The innovation of seamlessly merging the ownership models and selling IaaS and SaaS products to other organizations provides it with a competitive advantage.

The marketing of cloud computing capability is an important enabler of change and competitive advantage as highlighted in Organization B.

The operational aspects of cloud computing will also provide short term benefits to organizations, especially when using IaaS. These benefits can easily be recreated and will not provide long term competitive advantage.

Cloud models and ownership enablers provide propensities for utility and transformation in organizations. An organization using IaaS in a public cloud is likely to be in a utility market unless other enablers in the BDN coupled with powerful changes are able to deliver benefits. In the case studies a shallow analysis of Organization D would view their heavy reliance on IaaS as a utility approach. However, the usage of hybrid clouds coupled with a strong change culture has delivered benefits and an investment portfolio that has captured new customers. An organization using PaaS and a private cloud has enablers that deliver many benefits. However, without a BDN to deliver the benefits the enablers would be lost.

The power of short term enablers should not be underestimated. Organization B has used marketing as a powerful short term enabler. The leadership understand this can be replicated by competitors in the long term. The organization will then use PaaS as a longer term enabler.

All organizations have used operational gains from cloud computing, to generate competitive advantage in the short term and have strategies in place for the longer term. 


\section{CONCLUSION}

This paper has described a number of aspects of cloud computing in terms of procurement and ownership models. The Benefits Management approach has been defined. A major contribution of the paper is to undertake a number of case studies on diverse organizations to understand how these organizations use procurement and ownership models to derive benefits from cloud computing.

The conclusions from the case studies outline the beginnings of a "database" which can be used by organizations when considering cloud computing investments. Further case studies will add to the knowledge and robustness of the portfolio of case studies.

Another contribution of this paper is to consider the expressive power of existing Benefits Management tools. It is felt that the tools may not be powerful enough to consider the complexity of cloud computing investments across a number of organizations. Work is underway to consider more powerful knowledge representation techniques.

\section{FUTURE WORK}

On reviewing the case studies presented in this paper it can be seen that there is a complexity in and between cloud enablers, change, benefits and investments. The tools provided by traditional Benefits Management provide basic network interconnections between elements and simplistic representations of the Benefits Management elements.

A more powerful knowledge representation method is required. It is proposed to model the Benefits Management process as an ontology and to populate the ontology with the case studies described in this paper and further case studies.

The Benefits Management ontology is strongly related to pricing models already developed for cloud computing [24]. The two ontologies can be mapped to consider the value of benefits derived from cloud computing investments.

\section{REFERENCES}

[1] J. Ward and E. Daniel, Benefits Management: How to Increase the Business Value of Your IT Projects. Wiley, 2012.

[2] M. Cusumano, "Cloud computing and SaaS as new computing platforms," Communications of the ACM, vol. 53, no. 4, pp. 27-29, 2010.

[3] R. L. Grossman, "The Case for Cloud Computing," IT Professional, vol. 11, no. 2, pp. 23-27, Apr. 2009.

[4] P. Mell and T. Grance, "The NIST definition of cloud computing (draft)," NIST special publication, vol. 800, no. 145, p. 7, 2011.

[5] D. Agrawal, "Towards the End-to-End Design for Big Data Management in the Cloud: Why, How, and When?," presented at the BTW, 2013, pp. 15-16.
[6] I. T. Foster and R. K. Madduri, "Science as a service: how on-demand computing can accelerate discovery," presented at the Proceedings of the 4th ACM workshop on Scientific cloud computing, 2013, pp. 1-2.

[7] R. Moreno-Vozmediano, R. S. Montero, and I. M. Llorente, "Key Challenges in Cloud Computing: Enabling the Future Internet of Services," Internet Computing, IEEE, vol. 17, no. 4, pp. 18-25, 2013.

[8] C. Low, Y. Chen, and M. Wu, "Understanding the determinants of cloud computing adoption," Industrial management \& data systems, vol. 111, no. 7, pp. 1006-1023, 2011.

[9] S. C. Misra and A. Mondal, "Identification of a company's suitability for the adoption of cloud computing and modelling its corresponding Return on Investment," Mathematical and Computer Modelling, vol. 53, no. 3, pp. 504-521, 2011.

[10] Y. Han, "Cloud computing: case studies and total cost of ownership," Information technology and libraries, vol. 30, no. 4, pp. 198-206, 2011.

[11] A. B. Mohammed, J. Altmann, and J. Hwang, "Cloud computing value chains: Understanding businesses and value creation in the cloud," in Economic models and algorithms for distributed systems, Springer, 2010, pp. 187-208.

[12] M. E. Porter, "Towards a dynamic theory of strategy," Strategic Management Journal, vol. 12, no. S2, pp. 95-117, 1991.

[13] J. Peppard, J. Ward, and E. Daniel, "Managing the realization of business benefits from IT investments," MIS Quarterly Executive, vol. 6, no. 1, pp. 1-11, 2007.

[14] J. Peppard and A. Rylander, "From Value Chain to Value Network:: Insights for Mobile Operators," European Management Journal, vol. 24, no. 2-3, pp. 128-141, Apr. 2006.

[15] J. Ward and E. Daniel, "How to deliver more business benefits from IT investments," The European Financial Review, pp. 27-30, 2013.

[16] J. S. Harrison, D. A. Bosse, and R. A. Phillips, "Managing for stakeholders, stakeholder utility functions, and competitive advantage," Strategic Management Journal, vol. 31, no. 1, pp. 58-74, 2010.

[17] J. Highsmith, Agile Project Management: Creating Innovative Products, 2nd ed. Addison-Wesley Professional, 2009.

[18] E. Daniel, "Breakfast Briefing presentation 29th November 2012." Open University, 2012.

[19] H. Weihrich, "The TOWS matrix - a tool for situational analysis," Long range planning, vol. 15, no. 2, pp. 54-66, 1982.

[20] M. Armbrust, A. Fox, R. Griffith, A. D. Joseph, R. Katz, A. Konwinski, G. Lee, D. Patterson, A. Rabkin, I. Stoica, and others, "A view of cloud computing," Communications of the ACM, vol. 53, no. 4, pp. 50-58, 2010

[21] D. C. Wyld, "The Cloudy future of government IT: Cloud computing and the public sector around the world," International Journal of Web \& Semantic Technology, vol. 1, no. 1, pp. 1-20, 2010.

[22] S. LaValle, E. Lesser, R. Shockley, M. S. Hopkins, and N. Kruschwitz, "Big data, analytics and the path from insights to value," MIT Sloan Management Review, vol. 52, no. 2, pp. 21-31, 2011.

[23] M. R. Catherine and E. B. Edwin, "A Survey on Recent Trends in Cloud Computing and its Application for Multimedia," International Journal of Advanced Research in Computer Engineering \& Technology (IJARCET), vol. 2, no. 1, p. pp-304, 2013.

[24] R. Greenwell, X. Liu, and K. Chalmers, "Pricing Intelligence as a service for Cloud computing." IEEE Cloudcom 2013, 2013. 